\title{
THE SPECIFICITY OF AGGLUTINATION REACTIONS OF PSEUDOMONAS AERUGINOSA WITH O ANTISERA
}

\author{
T. L. Pitt and Y. J. ERdman* \\ Cross-Infection Reference Laboratory, Central Public Health Laboratory, Colindale Avenue, \\ London NW9 $5 H T$
}

THE identification of heat-stable somatic antigens is the most widely used method for the serological typing of Pseudomonas aeruginosa. A number of serotyping schemes have been proposed (Habs, 1957; Verder and Evans, 1961; Meitert, 1964; Lányi, 1966-67; Homma et al., 1970) and several numbering systems have been employed for the $\mathrm{O}$ serotypes or serogroups of $P$. aeruginosa; we accept the proposal (P. V. Liu, personal communication, 1976) that the numbering system of Habs (1957) should be used for the first 12 serogroups and that higher numbers should be used for additional groups described subsequently by other workers (see also Bergan, 1975).

Most of the $\mathrm{O}$ serogroups of $P$. aeruginosa are antigenically distinct, and strains can be allocated to them by agglutination tests with rabbit antisera, usually without need to remove cross-reacting antibodies by absorption. However, a minority of strains that are stable in saline suspension are agglutinated by several antisera prepared against apparently unrelated $O$ serogroups. These "polyagglutinable" (PA) strains were reported as "non-groupable" by Lányi (1966-67) and Homma et al. 11970). Duncan et al. (1976) absorbed their typing sera with strain SMC-247 which showed a wide pattern of crossagglutination; they found that other PA strains gave monospecific reactions with the absorbed sera. We have compared this method with a number of other techniques for the elimination of cross-reactions in the $\mathrm{O}$ serotyping of PA strains.

\section{MATERIALS AND METHODS}

Organisms. One representative strain (the type strain) of each of the following serotypes of $P$. aeruginosa was used for serum production: Habs' types 1-12 (Habs, 1957); the subtypes of types 2 and 5, namely "types" $2 \mathrm{~b}$ and $5 \mathrm{~d}$ (Véron, 1961); type 13, the "type II " of Sandvik (1960); type 15, the " group 12" of Lányi (1966-67); type 16 (strain Ps11 [Lányi, 1966-67], related to the "2-5 complex"); type 17, the " type X" of Meitert (1964). $P$. aeruginosa strain SMC-247 was a gift from Dr Norma Duncan, Department of Microbiology, University of Ontario, Toronto, Canada. A further 1850 strains of $P$. aeruginosa were received from various sources for typing in our laboratory.

Staphylococcus aureus strain NCTC8530, which is rich in protein A, was used in co-agglutination tests.

Media and solutions. Nutrient Broth No. 2 (Oxoid) was used throughout for liquid culture and $1 \%(\mathrm{w} / \mathrm{v})$ of agar was added to make nutrient agar. Saline was $0.85 \%(\mathrm{w} / \mathrm{v})$ aqueous $\mathrm{NaCl}$, and phenol saline was saline with phenol added to a final concentration of $0.5 \%(\mathrm{w} / \mathrm{v})$. Phosphate-buffered saline (PBS; 0.002M) was prepared by dissolving tablets of PBS reagent

Received 9 May 1977; accepted 13 June 1977.

* Present address: Diagnostic Bacteriology Laboratory, St. Mary's Hospital Medical School, Paddington, London W2 1PG.

J. MED. MICROBIOL.-VOL. 11 (1977) 
(Dulbecco "A"; Oxoid) in distilled water. The 2-mercaptoethanol (2-ME) reagent was a $0.05 \mathrm{M}$ solution of 2-mercaptoethanol (BDH Chemicals Ltd, Poole, Dorset) in saline.

Preparation of antisera. A 5-ml volume of broth was inoculated with 10 colonies of the type strain from an agar plate and, after incubation at $37^{\circ} \mathrm{C}$ for $4 \mathrm{~h}$, used to seed a $100-\mathrm{ml}$ volume. The latter was incubated at $37^{\circ} \mathrm{C}$ for $18-24 \mathrm{~h}$ with constant agitation. The cells were harvested by centrifugation at $3000 \mathrm{~g}$ for $30 \mathrm{~min}$., resuspended in $20 \mathrm{ml}$ of saline and boiled for $2.5 \mathrm{~h}$. The opacity corresponded to that of tube no. 5 (Wellcome Opacity Tubes, Burroughs Wellcome, Beckenham, Kent) which was the equivalent of $c .3 .5 \times 10^{9}$ cells per ml.

Rabbits were given six intravenous injections of this vaccine at 3-4 day intervals in the following volumes $(\mathrm{ml}): 0 \cdot 25,0 \cdot 5,1 \cdot 0,1 \cdot 5,2 \cdot 0$ and $2 \cdot 0$. The animals were exsanguinated 3 days after the final injection, and the serum was separated and clarified by centrifugation. Merthiolate (Thiomersal) at a final concentration of 1 in $5000(\mathrm{w} / \mathrm{v})$ was added as a preservative; the serum was dispensed in $5-\mathrm{ml}$ volumes and stored at $-20^{\circ} \mathrm{C}$.

Agglutination tests. The overnight growth from an agar-slant culture was suspended in c. $5 \mathrm{ml}$ of phenol saline. The cells (approximately $10^{10}$ ) were deposited by centrifugation and resuspended in $1 \mathrm{ml}$ of saline. Sera diluted initially to 1 in 20 were tested in doubling dilutions for agglutinin with the homologous strain and all the heterologous type strains, and cross-reacting antibody was removed by appropriate absorptions (see below). In routine typing tests, strains were tested with a single dilution of serum four times lower than the highest dilution that gave strong agglutination with the homologous strain. Strains were tested first with four pools of sera and subsequently with the individual sera.

Treatment of sera with 2-ME. Antisera were diluted 1 in 50 in the 2-ME reagent immediately before use in agglutination tests.

Absorption of sera. Overnight growth of the absorbing strain from five 9-cm agar plates was harvested in $20 \mathrm{ml}$ of saline and deposited by centrifugation. The deposit was resuspended in $4.5 \mathrm{ml}$ of phenol saline and $0.5 \mathrm{ml}$ of antiserum was added. The mixture was incubated at $37^{\circ} \mathrm{C}$ for $2 \mathrm{~h}$ and then held at $4^{\circ} \mathrm{C}$ overnight. After the removal of the bacteria by centrifugation at $3000 \mathrm{~g}$ for $1 \mathrm{~h}$, the serum was passed through a sterilising-grade membrane filter (Millipore).

Precipitation tests. Antigen extracts of cultures were usually prepared by heating at $100^{\circ} \mathrm{C}$ for $1 \mathrm{~h}$ the centrifuged deposit of overnight growth from a 5 -ml agar-slant culture resuspended in $1.0 \mathrm{ml}$ of saline. The supernate after centrifugation was the extract. When necessary, extracts were prepared with $0.6 \mathrm{M}$ trichloracetic acid (Boivin and Mesrobeanu, 1937). Precipitation tests were performed by the double-diffusion method (Ouchterlony, 1949 ) in $1 \%$ Ionagar (Oxoid) on microscope slides $(75 \mathrm{~mm} \times 25 \mathrm{~mm})$.

Co-agglutination tests with $S$. aureus. A suspension of the protein A-containing staphylococcus was prepared by the method of Kronvall (1973) as follows. A formaldehyde- and heat-treated staphylococcal suspension was centrifuged and a $10 \%(\mathrm{v} / \mathrm{v})$ suspension in saline was prepared from the packed cells; $1 \mathrm{ml}$ of this suspension was mixed with $0.1 \mathrm{ml}$ of the typing serum and left at room temperature for $10 \mathrm{~min}$. The staphylococcal cells were washed once with saline and resuspended to $1 \%(\mathrm{v} / \mathrm{v})$ in saline. One drop of this suspension was mixed on a slide with a thick saline suspension of the test strain of $P$. aeruginos $a$ harvested from an agar plate; the mixture was examined for agglutination within $10 \mathrm{~s}$.

Fractionation of antiserum. A suspension of Sepharose 4B (Pharmacia Ltd, Uppsala, Sweden) was diluted to a consistency that allowed the easy escape of air bubbles and was evenly packed into a column $30 \mathrm{~cm} \times 1.5 \mathrm{~cm}$. The void volume was determined with Dextran Blue 2000 (Pharmacia Ltd). The serum sample $(1 \mathrm{ml})$ was applied, washed in twice with its own volume of PBS, and eluted with the same buffer at a flow rate of 25-30 ml per $\mathrm{h}$; sixty $1-\mathrm{ml}$ fractions were collected. The protein content of each fraction was determined by measuring the absorbance at $280 \mathrm{~nm}$ with a Unicam SP1800 spectrophotometer (Pye Unicam Ltd, Cambridge, England). Each fraction was tested by double diffusion with specific goat anti-rabbit-IgG serum (Miles-Yeda Ltd, Rehovot, Israel) and sheep antirabbit-IgM serum (Nordic Laboratories, Tilburg, the Netherlands). Slide-agglutination tests with live agar-grown cultures were performed on all fractions.

Phage typing. The method of Asheshov (1974) was used. 


\section{RESULTS}

\section{Frequency of occurrence of $P A$ strains}

During a period of 12 months, 1850 cultures from 19 hospitals or groups of hospitals were received for serological typing. Of these, $70(3.8 \%)$ isolates were agglutinated by more than one typing serum, excluding the recognised cross-reactions within $\mathrm{O}$ groups 2 and 5 , and 7 and 8 . Polyagglutination of cultures was most commonly observed with antisera to $O$ groups 3, 6, 10 and 13 and cross-reactions with antisera to $O$ groups 4, 5, 9 and 11 occurred less frequently.

Fifty-two epidemiologically-independent PA strains were selected for study. A strain was considered independent if it was (1) the only PA strain isolated in connexion with an incident of infection at a particular centre, or (2) if it differed in phage-typing pattern from other PA strains from such an incident.

\section{Agglutination tests with absorbed antisera}

Antisera to $O$ groups 3, 4, 5, 6, 9, 10, 11 and 13 were absorbed with strain SMC-247 and agglutination tests were performed with the PA strains and the absorbed sera. Most of the strains ( 42 out of 52) were agglutinated by a single absorbed serum (table I). The remaining 10 strains were not agglutinated by any of the sera. Of the typable strains, 19 fell in $O$ group 3, 10 in $O$ group 6,

\section{TABLE I}

Results of $O$ grouping of $P A$ cultures by (a) agglutination with sera absorbed with strain SMC$247,(b)$ double-diffusion precipitation tests in gel with unabsorbed sera, and

(c) co-agglutination with staphylococci treated with unabsorbed sera

\begin{tabular}{|c|c|c|c|}
\hline \multirow[t]{2}{*}{ O group } & \multicolumn{3}{|c|}{$\begin{array}{l}\text { Number of PA cultures, of } 52 \text { examined, } \\
\text { allocated to the specified O group by } \\
\text { method }\end{array}$} \\
\hline & (a) & (b) & $(c)$ \\
\hline $\mathrm{O} 3$ & 19 & 21 & 20 \\
\hline $\mathrm{O} 4$ & 2 & 2 & 2 \\
\hline O6 & 10 & 10 & 11 \\
\hline O9 & 1 & 1 & 1 \\
\hline $\mathrm{O} 10$ & 7 & 4 & 7 \\
\hline 011 & 3 & 1 & 3 \\
\hline Any single $O$ group & 42 & 39 & 44 \\
\hline Two or more $\mathrm{O}$ groups & 0 & 7 & 0 \\
\hline None & 10 & 6 & 8 \\
\hline
\end{tabular}


7 in $O$ group 10, 3 in $O$ group 11, 2 in $O$ group 4 and one in $O$ group $9 . \quad$ No cross-reactions were observed, and agglutination was usually strong and easily visible. These results confirmed the finding of Duncan et al. (1976).

\section{Precipitation tests with unabsorbed antisera}

As Köhler (1957) had shown that the precipitin and agglutinin in serum to the $\mathrm{O}$ antigen of $P$. aeruginosa were indistinguishable, the correlation between a precipitin test in gel and the agglutination test with absorbed sera was investigated. Boiled saline extracts of PA strains usually proved suitable antigens for the demonstration of precipitins in unabsorbed sera and in only a few instances, when boiled extracts failed to precipitate with antibody in gel, were trichloracetic acid extracts necessary to obtain precipitin lines in gel diffusion tests.

Extracts of 39 strains (table I) reacted with a single antiserum, and in 37 instances the results corresponded with those of the agglutination test; two strains that were untypable by agglutination were allocated to $O$ group 3 by precipitation. However, three strains allocated to $O$ group 10 and two strains allocated to $O$ group 11 by agglutination tests gave no reaction in the precipitation test, and seven strains reacted with two or more sera.

\section{Differentiation of cross-reacting and $O$-specific antibodies}

Homma et al. (1971) showed that rabbit antisera against $P$. aeruginosa contained immunoglobulins of classes IgG and IgM, and that both were responsible for $\mathrm{O}$-specific agglutination. To investigate the immunoglobulin class of the cross-reacting antibodies, a protein A-containing staphylococcus was separately treated with each of the unabsorbed typing antisera that had contributed to the cross-reactions (sera against $O$ groups $3,4,6,10,11$ and 13). Co-agglutination tests with sensitised staphylococci and PA strains gave monospecific reactions. Forty-four of the 52 strains were allocated to an $O$ serogroup by this method; 42 strains gave results that agreed with those of the conventional agglutination test with sera absorbed with strain SMC-247, and two additional strains were allocated to a serogroup (one each to groups 3 and 6 ; table I). These findings suggested that the cross-reactions were attributable to antibodies other than IgG.

The unabsorbed sera were therefore treated with 2-ME and then used in agglutination tests with five selected PA strains that had been allocated to each of the $O$ serogroups 3, 4, 6, 10 and 11 by all three of the previous tests (table I). Most of the cross-reactions were removed by 2-ME treatment (table II); the use of treated sera caused three of the strains to give the " correct " monospecific reactions, and the other two strains to react strongly with the " homologous" serum and weakly with other sera.

The supernates from the same sera after absorption with the protein Acontaining staphylococcus were used in conventional agglutination tests with the same five strains of $P$. aeruginosa. The results (table II) indicated that this absorption did not remove cross-reacting agglutinins. 
TABLE II

Specific and cross-reacting agglutination of selected PA strains by (a) unabsorbed sera, $(b)$ antisera treated with 2-ME, and (c) antisera after absorption with protein A-containing staphylococci

\begin{tabular}{rc|lll}
\hline Strain & $\begin{array}{c}\text { Presumptive } \\
\text { O group* }\end{array}$ & \multicolumn{3}{|c}{$\begin{array}{c}\text { O-group antisera that produced } \\
\text { agglutination by method }\end{array}$} \\
\cline { 3 - 5 } 160 & 03 & $3,6,(10), 13 \dagger$ & 3 & $(c)$ \\
793 & O4 & $3,4,13$ & $(3), 4$ & $3,6,10,13$ \\
1261 & O11 & $3,(4), 11$ & 11 & $(3), 4,11$ \\
1427 & O10 & $3,10,(13)$ & $(3,13) 10$ & $3,10,13$ \\
1487 & O6 & $3,6,10,13$ & 6 & $3,6,10,13$ \\
\hline
\end{tabular}

* As determined by (1) agglutination by sera absorbed with strain SMC-247, (2) gel-precipitation, and (3) co-agglutination tests (see table I).

$\dagger$ Identification ( $O$ serotype) numbers of sera causing agglutination.

( ) = Weak reaction.

\section{Confirmation of the $O$ groups of $P A$ strains}

It was necessary to show that each of the five selected PA strains removed, from the "homologous" typing antiserum, antibody not only against itself but also against the type strain used to prepare the antiserum. Table III shows the agglutinin titre of the serum of the presumed type of the PA strain, with the type strain and with the test strain, before and after absorption of the serum with the test strain. For example, $O$ group 3 serum agglutinated the

\section{TABLE III}

Removal of specific antibody from typing antisera by absorption with $P A$ strains presumed to belong to the corresponding $O$ serogroup

\begin{tabular}{|c|c|c|c|c|c|}
\hline \multirow[t]{2}{*}{ Test strain } & \multirow[t]{2}{*}{$\begin{array}{l}\text { O-group } \\
\text { antiserum }\end{array}$} & \multicolumn{2}{|c|}{$\begin{array}{l}\text { Agglutinin titre with } \\
\text { unabsorbed O-group } \\
\text { antiserum against }\end{array}$} & \multicolumn{2}{|c|}{$\begin{array}{l}\text { Agglutinin titre with } \\
\text { O-group antiserum } \\
\text { absorbed with test } \\
\text { strain against }\end{array}$} \\
\hline & & $\begin{array}{l}\text { serotype } \\
\text { strain }\end{array}$ & $\begin{array}{c}\text { test } \\
\text { strain }\end{array}$ & $\begin{array}{l}\text { serotype } \\
\text { strain }\end{array}$ & $\begin{array}{l}\text { test } \\
\text { strain }\end{array}$ \\
\hline 160 & O3 & 640 & 320 & 40 & $<20$ \\
\hline 793 & O4 & 640 & 320 & 40 & $<20$ \\
\hline 1261 & O11 & 320 & 320 & 20 & 20 \\
\hline 1427 & $\mathrm{O} 10$ & 160 & 160 & $<20$ & $<20$ \\
\hline 1487 & O6 & 640 & 640 & 40 & 40 \\
\hline
\end{tabular}


type strain to a titre of 640 and strain 160 to a titre of 320 ; after absorption with strain 160 the titres were respectively 40 and $<20$. In all instances, the titre of agglutinin against the test strain was within one tube of the titre of agglutinin against the type strain, and absorption with the test strain removed most or all of the agglutinating antibody against the type strain.

\section{Separation of IgG and IgM in typing antisera}

Two unabsorbed sera that frequently contributed to PA reactions, $\mathrm{O6}$ and O13, were chosen, and $1.0 \mathrm{ml}$ of each was fractionated on Sepharose 4B. Double-diffusion tests in gel with specific anti-rabbit IgG and IgM sera were performed on all fractions. Separation of the antibody classes was obtained; early fractions contained only IgM, intermediate fractions contained both IgM and IgG, and late fractions contained only IgG. All the fractions were tested by slide agglutination with the type strains $\mathrm{O} 6$ and $\mathrm{O} 13$, and with the PA strains listed in table II. The type strains were agglutinated by both IgM and IgG fractions of the homologous O-group serum. The IgM fractions of serum O6 agglutinated two of the PA strains (nos. 160 and 1487), but the IgG fractions agglutinated only strain 1487 (table IV). We had already concluded (see table III) that strain 1487 belonged to serogroup O6. However, strain 160 had been allocated to serogroup $\mathrm{O} 3$ and was agglutinated only by the IgM fraction of the $\mathrm{O} 6$ antiserum, which supported the conclusion that the reaction with unabsorbed $\mathrm{O} 6$ antiserum was not $\mathrm{O}$-group specific.

\section{TABLE IV}

Agglutinins against $P A$ strains and serotype strains in the IgM and IgG of two $O$-group antisera

\begin{tabular}{|c|c|c|c|c|}
\hline \multirow{3}{*}{ Test } & \multicolumn{4}{|c|}{ Results of tests on serum } \\
\hline & \multicolumn{2}{|c|}{ O6, fractions* } & \multicolumn{2}{|c|}{ O13, fractions* } \\
\hline & $20-26$ & $33-41$ & $21-26$ & $33-38$ \\
\hline $\begin{array}{l}\text { Precipitation with antiserum against } \\
\text { rabbit IgM } \\
\text { rabbit IgG }\end{array}$ & \pm & $\overline{+}$ & \pm & $\bar{t}$ \\
\hline $\begin{array}{l}\text { Agglutination with PA strain } \\
160 \\
793 \\
1261 \\
1427 \\
1487\end{array}$ & $\begin{array}{l}\frac{+}{-} \\
\frac{+}{+}\end{array}$ & $\begin{array}{l}\overline{-} \\
\overline{-} \\
\overline{+}\end{array}$ & $\begin{array}{l}+ \\
\pm \\
\pm \\
\pm \\
+\end{array}$ & $\begin{array}{l}- \\
- \\
- \\
-\end{array}$ \\
\hline $\begin{array}{l}\text { Agglutination with serotype strain } \\
\text { O6 } \\
\text { O13 }\end{array}$ & \pm & \pm & $\bar{t}$ & $\bar{t}$ \\
\hline
\end{tabular}

* Fractions obtained by gel filtration on Sepharose 4B.

$+=$ Positive reaction; $\pm=$ weak reaction; $-=$ no reaction. 
None of the five PA strains had been allocated to $\mathrm{O}$ group 13, and all the reactions with $\mathrm{O} 13$ serum were obtained only with the IgM fractions of this serum. Four strains had given agglutination reactions with unabsorbed 013 serum. Strain 1261 was not agglutinated by unabsorbed 013 serum, but a weak reaction was obtained with the corresponding IgM fraction; this may be explained by the greater dilution of the serum used in the former test.

Fractions of $\mathrm{O} 13$ antiserum containing IgM were absorbed with PA strain 160 and were then tested by slide agglutination with the PA strains and with type strain O13. None of the PA strains was agglutinated by the absorbed IgM antiserum but the type strain was still strongly agglutinated. This indicated that both type-specific and non-specific antibodies were present in the IgM fractions of $\mathrm{O} 13$ antiserum. Absorption with one PA strain removed agglutinating antibody to the other four strains in this series, suggesting that the PA antigen of these strains was similar.

\section{DisCuSSION}

Several workers have encountered polyagglutinability in the $\mathrm{O}$ serotyping of $P$. aeruginosa (Christie, 1948; Lányi, 1966-67; Homma et al., 1970). Lányi (1966-67) found that all PA strains were agglutinated by the same antisera, and suggested that the heat-stable antigenic determinants responsible for polyagglutination in these strains might be identical. Mikkelsen (1970) also concluded that a heat-stable surface determinant distinct from the $O$ antigen was responsible for many of the cross-reactions between $\mathrm{O}$ serogroups. Our study has confirmed that the substance responsible for polyagglutinability is heat stable and that the antibody against it is distinct from $\mathrm{O}$ antibody. This is supported by the finding that chemical analysis of the polysaccharide portion of the cell-wall lipopolysaccharide, which is associated with the specificity of the $O$ antigen (Chester, Meadow and Pitt, 1973), shows no significant difference between a typable culture and a PA culture derived from it (Chester and Meadow, 1975).

Polyagglutinability has been encountered with varying frequency by different observers. Martin (1971) found that PA strains were often isolated from patients with cystic fibrosis and chronic bronchitis. There was some association between polyagglutinability and the mucoid colony form, often encountered among isolates from these patients, but many non-mucoid strains were also polyagglutinable. None of our isolates came from patients in cysticfibrosis units, and this may be one reason why PA strains occurred infrequently.

Technical factors also have an important influence on the frequency with which cross-reactions are observed in the $\mathrm{O}$ serotyping of $P$. aeruginosa. Mikkelsen (1970) observed that sera prepared by the injection of concentrated whole-cell vaccines with the object of obtaining high titres of $\mathrm{O}$ antibody gave many cross-reactions. Duncan et al. (1976) reported a much greater percentage of polyagglutinable strains $(28 \%)$ than we found $(3.8 \%)$. This may be partly attributed to their use of concentrated agar-grown cultures $\left(c .5 \times 10^{10}\right.$ cells per $\mathrm{ml}$ ) for the preparation of antisera. For some years we have used broth-grown 
cultures (c. $3.5 \times 10^{9}$ cells per $\mathrm{ml}$ ), having observed that this reduced considerably the number of polyagglutination reactions.

Nevertheless, we confirm that absorption of typing sera with strain SMC-247 is a valuable method of reducing further the number of strains that react with two or more antigenically unrelated sera. Co-agglutination of bacterial suspensions with staphylococci that had been treated with unabsorbed serum was at least as effective, and we consider this to be the method of choice. Both methods were clearly superior in sensitivity and specificity to precipitation tests in gel with boiled-culture supernates or trichloracetic-acid extracts and unabsorbed sera. It was surprising to find, however, that with unabsorbed sera the precipitation test gave more specific results than the conventional agglutination test; the PA antigen may not be a good precipitinogen, or the O-specific IgG antibody may be a more effective precipitin than the IgM antibody.

The observation that the PA antigen elicits only an IgM antibody response, but that $O$ antibody is present both as IgM and IgG, was unexpected. In adult animals, the early immune response consists of IgM antibody, which has a shorter half-life than IgG antibody (Wilson and Miles, 1975). It is not possible to use this fact to obtain typing sera of improved specificity by " late " bleeding, because the O-antibody titre decreases rapidly after the third week of an immunisation course, whether or not immunisation is continued.

The use either of antisera absorbed with strain SMC-247 or of coagglutination tests with unabsorbed sera reduced the proportion of polyagglutinable strains by $80 \%$. At present, only about $4 \%$ of our isolatesexcept those from chronic respiratory-tract infections-are polyagglutinable in conventional agglutination tests, and either method would improve the success of serotyping by approximately $3 \%$.

\section{SUMMARY}

Polyagglutinable (PA) strains of Pseudomonas aeruginosa are agglutinated by more than one of the antisera prepared against antigenically unrelated $O$ serogroups. They form $c .4 \%$ of strains-other than isolates from cysticfibrosis units-submitted to us for typing. We were able to allocate $80 \%$ of PA strains to a single $O$ serogroup by agglutination with typing sera that had been absorbed with the polyagglutinable strain SMC-247, or by co-agglutination tests with protein A-containing staphylococci coated with immunoglobulin from unabsorbed sera. Similar results were obtained by precipitation tests with crude bacterial extracts and unabsorbed sera, but these tests were less sensitive and less specific. Evidence is presented that PA antigen is a heat-stable cell constituent distinct from the $\mathrm{O}$ antigen. In rabbit antisera, anti-PA antibody is exclusively of the IgM class, but $\mathrm{O}$ antibody of both IgM and IgG classes is present.

\section{REFERENCES}

AsHeSHOV, E. H. 1974. An assessment of the methods used for typing strains of Pseudomonas aeruginosa. In Proceedings of the sixth national congress of bacteriology, edited by A. Arseni, Athens, p. 9. 
Bergan, T. 1975. Epidemiological typing of Pseudomonas aeruginosa. In Resistance of Pseudomonas aeruginosa, edited by M. R. W. Brown, New York, p. 189.

Boivin, A. ANd MesRobeanu, L. 1937. Sur l'antigène O; endotoxine des pyocyaniques. C. r. Séanc. Soc. Biol., 125, 273.

CHESTER, I. R. AND MEADOW, P. M. 1975. Heterogeneity of the lipopolysaccharide from Pseudomonas aeruginosa. Eur. J. Biochem., 58, 273.

Chester, I. R., Meadow, P. M. AND PitT, T. L. 1973. The relationship between the Oantigenic lipopolysaccharides and serological specificity in strains of Pseudomonas aeruginosa of different O-serotypes. J. gen. Microbiol., 78, 305.

CHRISTIE, R. 1948. Observations on the biochemical and serological characteristics of Pseudomonas pyocyanea. Aust. J. exp. Biol. med. Sci., 26, 425.

Duncan, N. H., Hinton, N. A., Penner, J. L. And Duncan, I. B. R. 1976. Preparation of typing antisera specific for $\mathrm{O}$ antigens of Pseudomonas aeruginosa. J. clin. Microbiol., $4,124$.

HABs, I. 1957. Untersuchungen über die O-Antigene von Pseudomonas aeruginosa. Z. Hyg. InfektKrankh., 144, 218.

Homma, J. Y., Kim, K. S., Yamada, H., Ito, M., Shionoya, H. and Kawabe, Y. 1970. Serological typing of Pseudomonas aeruginosa and its cross infection. Jap.J.exp. Med., 40, 347.

Homma, J. Y., Shionoya, H., Yamada, H. ANd Kawabe, Y. 1971. Production of antibody against Pseudomonas aeruginosa and its serological typing. Jap. J. exp. Med., 41, 89.

KöHLER, W. 1957. Zur Serologie der Pseudomonas aeruginosa. Z. ImmunForsch. exp. Ther., 114, 282.

KronVALL, G. 1973. A rapid slide-agglutination method for typing pneumococci by means of specific antibody adsorbed to protein A-containing staphylococci. J. med. Microbiol., 6, 187.

LÁNYI, B. 1966-67. Serological properties of Pseudomonas aeruginosa 1. Group-specific somatic antigens. Acta microbiol. hung., 13, 295.

Martin, D. R. 1971. Variation in Pseudomonas aeruginosa. Ph.D. Thesis, University of London.

MeItERT, T. 1964. Contribution à l'étude de la structure antigènique des B. pyocyaniques (Pseudomonas aeruginosa). II. Individualisation des groupes sérologiques au moyen des antigènes "O". Archs roum. Path. exp. Microbiol., 23, 679.

Mikkelsen, O. S. 1970. Serotyping of Pseudomonas aeruginosa. II. Results of an O group classification. Acta path. microbiol. scand., 78B, 163.

OUCHTERLONY, O. 1949. Antigen-antibody reactions in gels. Acta path. microbiol. scand., 26, 507.

SANDVIK, O. 1960. Serological comparison between strains of Pseudomonas aeruginosa from human and animal sources. Acta path. microbiol. scand., 48, 56.

Verder, E. AND Evans, J. 1961. A proposed antigenic schema for the identification of strains of Pseudomonas aeruginosa. J. infect. Dis., 109, 183.

VÉron, M. 1961. Sur l'agglutination de Pseudomonas aeruginosa: subdivision des groupes antigèniques $\mathrm{O} \cdot 2$ et $\mathrm{O} \cdot 5$. Annls Inst. Pasteur, Paris, 101, 456.

Wilson, G. S. AND MiLes, A. A. 1975. In Topley and Wilson's Principles of bacteriology, virology and immunity, 6th ed., edited by G. S. Wilson and A. A. Miles, London, vol. 2, p. 1381. 